\title{
ТЕРМІЧНИЙ ЗАХИСТ ТКАНИН ПРИ РАДІОЧАСТОТНІЙ АБЛЯЦІї
}

Ганжса B.O., магістр ganzha.vsta1997@gmail.com

Стасюк Ю.П., асистент stasuyk.yuriy@gmail.com

Вовянко С. I., к.б.н.

sivovianko@gmail.com

Кафедра БМІ, ФБМІ

Національний технічний університет України «Київський політехнічний інститут імені Ігоря Сікорського»,

Київ, Україна

\begin{abstract}
Реферат - Використання радіочастотного впливу для деструкиї патологічних тканин широко використовується при багатьох захворюваннях. Найбільш широке застосування метод радіочастотної абляції отримав при лікуванні аритмій завдяки досить високій безпечності процедури. Однак наявність ризиків є частиною усіх операчій. Уникнути або хоча б зменшити кількість ускладнень, викликаних надмірним термічним впливом, є одним з напрямків покращення процедури.

В даній роботі проводиться дослідження впливу низької температури, щео генерується охолоджуючим аплікатором, на величину деструкиї тканин серия при радіочастотній абляції. Даний метод термічного захисту забезпечить можливість уникати пошкоджень, що не є необхідними. Дослідження проводились за допомогою моделі, створеної в середовищі Сотsоl 5.4 Multiphysics. Залежність електропровідності від температури описана за допомогою лінійного рівняння $з$ постійним температурним коефіиієнтом.

Ключові слова - радіочастотна абляція, ускладнення, термічний вплив, захист біологічних тканин, моделювання методу термічного захисту.
\end{abstract}

\section{I. ВСТУП}

Радіочастотна абляція (РЧА) - один 3 сучасних видів деструкції патологічних тканин. Процедура легко переноситься, має високу ефективність, не вимагає тривалої реабілітації, дає можливість позбутися проблеми малоінвазивним шляхом (катетерна РЧА). Завдяки своїм перевагам технологія РЧА часто використовується при лікуванні різноманітних захворювань в багатьох областях, зокрема при лікуванні аритмій, раку, варикозної хвороби. Однак існує ряд можливих ускладнень, виникнення яких може привести до нових проблем із здоров'ям.

Найбільш відома область використання РЧА - серце. Лікування різноманітних порушень серцевого ритму за допомогою радіочастотного впливу є одним 3 відомих і ефективних методів боротьби 3 аритміями. Вперше методика РЧА при лікуванні фібриляції передсердь була застосована у 1998 році [1]. Від минулого століття і до сьогодні було виявлено багато нових можливостей застосування радіочастотного впливу при лікуванні серцевих хвороб. Були досліджені проблеми, які виникають в результаті апаратного i людського чинників. Однією 3 таких проблем стали ускладнення, викликані радіочастотним випромінюванням.

\section{II. ТЕРМІЧНИЙ ВПЛИВ ПРИ РЧА}

Процедура РЧА серця має свої особливості і різноманітні ускладнення, які можуть виникнути безпосередньо під час абляції. Найбільш серйозними вважають ускладнення, які призводять до незворотних змін або смерті, вимагають втручання або госпіталізації (або збільшення іiі тривалості) [2]. Наприклад, в сучасній практиці катетерної абляції різних видів тахіаритмій частота серйозних ускладнень варіюється від 0,8 до 6,0 \% в залежності від типу процедури і характеристик самого пацієнта [3].

Зрозуміло, що особливо висока ймовірність успіху при лікуванні, проведеному на ранніх стадіях захворювання, коли серцева деформація не досягнула значних розмірів, відповідно тоді нижча ймовірність ускладнень. Однак у певних випадках, незалежно від стадії 
захворювання, аритмогенна ділянка знаходиться надто близько до важливої зони, наприклад, провідної системи. Тоді видалення цієї тканини може спровокувати пошкодження нервів i, відповідно, порушення серцевої провідності. У такому випадку наслідки будуть залежати від важливості вражених клітин.

Наприклад, деструкція діафрагмального нерва $\epsilon$ добре вивченим ускладненням абляції усть легеневих вен. Частота виникнення - 11,2 \%. Небезпека пошкодження лівого діафрагмального нерва виникає при необхідності абляції вушка лівого передсердя. Такі ж причини деструкції блукаючого нерва, частота - біля $1 \%$ [4]. Способів профілактики не існує.

Також існують ускладнення, викликані надмірним термічним впливом, такі як перфорація або тампонада серця, атріовентрикулярні блокади різних ступенів, спазм і оклюзія коронарних артерій, та інші. Усі вони виникають через деструкцію прилеглих до ділянки аритмії анатомічних структур (діафрагмальних чи блукаючих нервів, коронарних артерій, стравоходу) [5].

\section{III. МОДЕЛЮВАННЯ РОЗПОДІЛУ ТЕМПЕРАТУРИ ПІД ЧАС РЧА}

Математичне моделювання термічної терапії широко використовується для прогнозування та оптимізації клінічних методів лікування та медичних приладів. Незалежно від методу, що використовується для досягнення нагрівання тканин, рівняння теплопередачі, яке необхідно вирішити для моделювання розподілу температури $\mathrm{T}\left({ }^{\circ} \mathrm{C}\right)$ в біологічних тканинах, має вигляд:

$$
\rho \mathrm{C} \frac{\partial \mathrm{T}}{\partial t}=\mathrm{k} \nabla^{2} \mathrm{~T}+\mathrm{Q}-\mathrm{Q}_{\mathrm{P}}
$$

де $\rho$ - щільність,

С - питома теплоємність,

$\mathrm{k}$ - теплопровідність,

Q - розподілене джерело тепла (втрати Джоуля),

$\mathrm{Q}_{\mathrm{P}}$ - втрати тепла, зумовлені перфузією крові.

Розподілене джерело тепла Q
задається

$$
\mathrm{Q}=\mathrm{J} \cdot \mathrm{E}
$$

де $\mathrm{J}$ - щільність струму,

E - напруженість електричного поля.

Значення цих двох векторів

оцінюються за допомогою рівняння Лапласа:

$$
\nabla \cdot \sigma \nabla \mathrm{V}=0
$$

де $\mathrm{V}$ - напруга,

$$
\sigma \text { - електропровідність. }
$$

Важливим фактором для досягнення реалістичних моделей $\epsilon$ використання математичних функцій для опису температурної залежності теплових i електричних властивостей тканини. Загально прийнятий підхід для моделювання температурної залежності теплових i електричних властивостей для температур нижче $100^{\circ} \mathrm{C}$ грунтується на лінійних рівняннях і використовує такі коефіцієнти постійної температури, як:

$$
\begin{aligned}
& \sigma(\mathrm{T})=\sigma 0[1+\mathrm{k} 1 \Delta \mathrm{T}] \\
& \varepsilon(\mathrm{T})=\varepsilon 0[1+\mathrm{k} 1 \Delta \mathrm{T}]
\end{aligned}
$$

де $\sigma 0$ - електропровідність,

$\varepsilon 0$ - діелектрична проникність,

k1 - температурний коефіцієнт,

$\Delta \mathrm{T}$ - різниця температур до еталонної температури.

Зауважимо, що для цих властивостей лінійне наближення $\epsilon$ адекватним лише в межах обмеженого діапазону температур [6].

Для побудови моделі РЧА в середовищі Comsol було застосовано два модулі - Electric currents та Heat transfer in solids, - i Multyphysics для задання граничних умов їхньої взаємодії.

Для створення термічного захисту у модель було добавлено аплікатор, який охолоджує тканини міокарду. Він розміщений над зоною 3 високою електропровідністю поблизу радіочастотного електрода. Аплікатори були заглиблені на 0,3 мм у матеріал, який відповідає біологічній тканині, для врахування натиску електрода на міокард.

Тканина під дією холоду підпадає під некротичний вплив при температурі нижче $-20^{\circ} \mathrm{C}$, тому для створення термічного захисту охолоджуючому аплікатору задається температура не нижче $-10^{\circ} \mathrm{C}$. Зрозуміло, що максимальне охолодження припадає на ділянку, що знаходиться безпосередньо біля контакту аплікатора 3 тканиною міокарда. 


\section{IV. РЕЗУЛЬТАТИ}

Процедура абляції міокарда проходить в декілька етапів. Спочатку аплікатор розміщується у потрібному місці процедура може проводитися на відкритому серці або катетерно. При цьому починається різке нагрівання самого аплікатора та відповідних тканин, що знаходяться безпосередньо біля нього. Потім тривалий процес теплообміну між суміжними біологічними тканинами, паралельно 3 яким відбувається охолодження конвекцією за рахунок потоку крові.

Необхідна для деструкції температура в ділянці контакту аплікатор-тканина досягається досить швидко, близько декількох секунд. Проте тканини, що розміщені глибше, дістати складніше, оскільки потрібен час на повне руйнування клітин, тому іноді для однієї точки тривалість контакту може досягати більше 60 с. Під час цього процесу важливо знайти компроміс між потребою знищити джерело аритмії та деструкцією здорових тканин, щоб уникнути виникнення небажаних наслідків, одним 3 видів яких $є$ феномен «газового вибуху» [7].

На рис. 2 показано суттєве зменшення зони деструкції при використанні термічного захисту, заданого 3 допомогою охолоджуючого аплікатора, встановленого на відстані 2 мм, температура якого становить $-5^{\circ} \mathrm{C}$. Потужність радіочастотного впливу, що використовувалась при моделюванні, становить $20 \mathrm{~B}$, частота - 500 кГц. На рисунках 1 і 2 виділено кольором межі незворотної деструкції, тобто синім кольором показана температура нижче $50^{\circ} \mathrm{C}$, а оранжевим - вище $50^{\circ} \mathrm{C}$ (зона деструкціi).

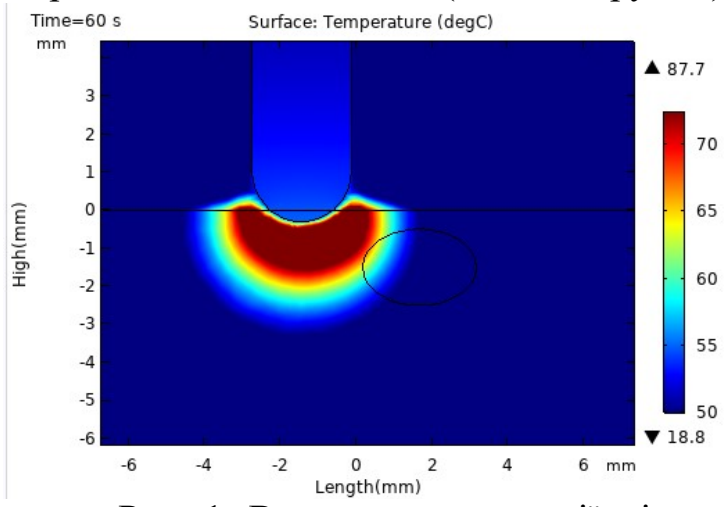

Рис. 1. Величина деструкції міокарду при стандартній процедурі РЧА

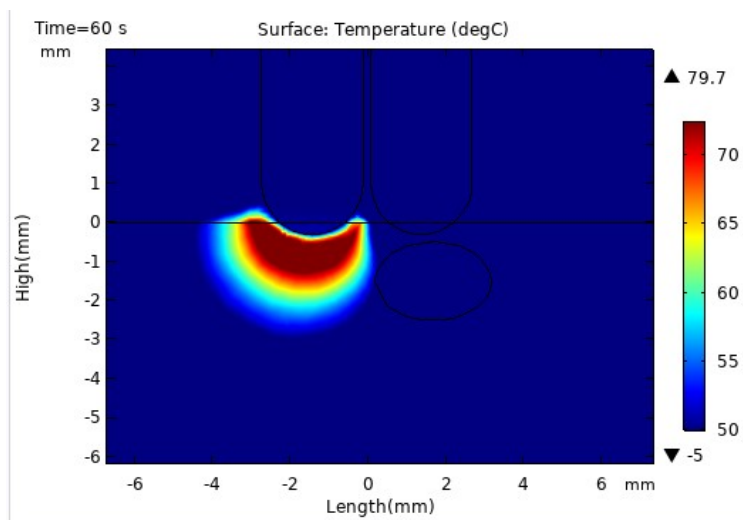

Рис. 2. Величина деструкції міокарду при РЧА з термічним захистом

Для порівняння даних моделей РЧА за наявності та відсутності впливу низьких температур розглянемо таблицю глибини незворотньої деструкції міокарда, яка наступає після $+50^{\circ} \mathrm{C}$, в залежності від температури охолоджуючого електроду, в точках на 0,7 мм зміщених в сторону радіочастотного аплікатора, вважаючи точкою початку відліку середину між двома аплікаторами (табл. 1). Дані зафіксовані через 30 с після початку впливу.

3 таблиці 1 видно, що наявність впливу холодом дозволяє зменшити глибину деструкції на мінімум 0,2 мм при температурі охолоджуючого аплікатора $0^{\circ} \mathrm{C}$ і нижче, тобто глибина деструкції зміниться не сильно, тоді як ширина досить значно (рис. 2, табл. 2).

В точках, на 0,7 мм зміщених в сторону охолоджуючого аплікатора температура $+50^{\circ} \mathrm{C}$ не досягається. У таблиці 2 представлено дані щодо ширини незворотньої деструкції.

Таблиия 1

Глибина деструкції міокарда у стандартній моделі РЧА та моделі з термічним захистом

\begin{tabular}{|c|c|c|}
\hline $\begin{array}{c}\text { Температура } \\
\text { охолоджуючого } \\
\text { аплікатора, }{ }^{\circ} \mathrm{C}\end{array}$ & $\begin{array}{c}\text { Глибина } \\
\text { деструкції } \\
\text { міокарда за } \\
\text { наявності } \\
\text { охолодж. } \\
\text { аплікатора, } \\
\text { мм }\end{array}$ & $\begin{array}{c}\text { Глибина } \\
\text { деструкції } \\
\text { міокарда за } \\
\text { відсутності } \\
\text { охолодж. } \\
\text { аплікатора, } \\
\text { мм }\end{array}$ \\
\hline 10 & 2,35 & \multirow{5}{*}{2,5} \\
\hline 5 & 2,3 & \\
\hline 0 & 2,3 & \\
\hline-5 & 2,25 & \\
\hline-10 & 2,2 & \\
\hline
\end{tabular}


Таблиия 2

Ширина деструкції міокарда у стандартній моделі РЧА та моделі з термічним захистом

\begin{tabular}{|c|c|c|}
\hline $\begin{array}{c}\text { Глибина } \\
\text { вимірювання, } \\
\text { мм }\end{array}$ & $\begin{array}{c}\text { Ширина } \\
\text { деструкції } \\
\text { міокарда при } \\
\text { температурі } \\
\text { охолодж. } \\
\text { аплікатора - } \\
5^{\circ} \mathrm{C}, \text { мм }\end{array}$ & $\begin{array}{c}\text { Ширина } \\
\text { деструкції } \\
\text { міокарда за } \\
\text { відсутності } \\
\text { охолодж. } \\
\text { аплікатора, } \\
\text { мм }\end{array}$ \\
\hline$-0,5$ & 4,05 & 5,2 \\
\hline-1 & 4,05 & 4,93 \\
\hline$-1,5$ & 3,6 & 4,42 \\
\hline-2 & 3,37 & 3,51 \\
\hline$-2,5$ & - & 2,8 \\
\hline
\end{tabular}

Аналіз даних, отриманих в результаті моделювання, показує явну залежність величини деструкції від наявності охолоджуючого деструктора. На різній глибині наявне зменшення ширини пошкодження, однак залежність не лінійна. 3 табл. 2 видно, що на глибині 2 мм різниця в величині деструкції найменша і становить 0,14 мм, тоді як на половину міліметра вище різниця становить уже $0,82 \mathrm{Mм}$, тобто $\epsilon$ значно більшою. Значним результатом є те, що на глибині 2,5 мм при використанні охолоджуючого аплікатора взагалі не досягається температура незворотньої деструкції, хоча при відсутності термічного захисту ширина пошкодження становить 2,8 MM.

\section{V. ВИСНОВКИ}

У результаті проведених досліджень доведено ефективність методу термічного захисту при РЧА. Аналіз отриманих даних показав, що:

1. Метод термічного захисту має ефективність завдяки наявності залежності електропровідності від температури та теплообміну.
2. Створення термічного захисту дозволяє уникнути надмірних пошкоджень тканини підчас РЧА.

3. При застосуванні термічного захисту під час РЧА, реалізованого завдяки додаванню охолоджуючого аплікатора, зменшення глибини незворотньої деструкції тканини під радіочастотним аплікатором становить 0,2 мм і більше.

4. Зменшення ширини незворотньої деструкції при наявності охолоджуючого аплікатора на глибині до 2 мм становить не менше 0,8 мм.

\section{ПЕРЕЛІК ПОСИЛАНЬ}

[1] А. В. Ардашев, Е. А. Долгушина, В. Н. Ардашев// Журнал "Коммерсантъ Наука" - 12.05.2017. - №3. - C. 14.

[2] Фібриляція передсердь. Адаптована клінічна настанова, заснована на доказах // Державний експертний центр Міністерства охорони здоров'я України, Асоціація кардіологів України, Асоціація аритмологів України, Українська асоціація сімейної медицини. - Київ. - 2016.

[3] Бокерия О. Л., Меликулов А. Х. Возможные осложнения катетерной аблации различных видов тахиаритмий // Анналы аритмологии. - 2011. - № 3. - T. 8.

[4] Воробьева, Д. О., Снежицкий В.А. Осложнения процедуры радиочастотной абляции у стьевлегочных вен при фибрилляции предсердий // Журнал Гродненского государственного медицинского университета. - 2017.

[5] Сичик М. М. Катетерна радіочастотна абляція аритмогенних зон серця підвищеної ефективності та безпечності. - Київ. -2017.

[6] Rossmann, C.,Haemmerich, D. Review of temperature dependence of thermal properties, dielectric properties, and perfusion of biological tissues at hyperthermic and ablation temperatures. Critical Reviewsin Biomedical Engineering. - 2014. - 42 (6). - C. 467-492.

[7] Стеклов В.И., Серговенцев А.А., Рзаев Ф.Г., Емельяненко М.В., Липская М.В., Валуев В.Е., Владимиров Ю.А. Радиочастотная катетерная абляция: биофизические основы и патофизиологические аспекты. // Вестник аритмологии. - 2018. 


\title{
ТЕРМИЧЕСКАЯ ЗАЩИТА ТКАНЕЙ ПРИ РАДИОЧАСТОТНОЙ АБЛЯЦИИ
}

Ганжа В.О., магистр ganzha.vsta1997@,gmail.com

Стасюк Ю.П., ассистент stasuyk.yuriy@gmail.com

Вовянко С. И., к.б.н. sivovianko@gmail.com Кафедра БМИ, ФБМИ

Национальный технический университет Украины «Киевский политехнический институт имени Игоря Сикорского»

Киев, Украина

Реферат - Использование радиочастотного воздействия для деструкции патологических тканей широко используется при многих заболеваниях. Наиболее широкое применение метод радиочастотной абляции получил при лечении аритмии благодаря достаточно высокой безопасности процедуры. Однако наличие рисков является частью всех операций. Избежать или хотя бы уменьшить количество осложнений, вызванных чрезмерным термическим воздействием, является одним из направлений улучшения процедуры.

В данной работе проводится исследование влияния низкой температуры, генерируемой охлаждающим аппликатором, на величину деструкции тканей сердиа при радиочастотной абляции. Данный метод термической защить обеспечит возможность избегать повреждений, которые не являются необходимыми. Исследования проводились с помощью модели, созданной в среде Comsol 5.4 Multiphysics. Зависимость электропроводности от температуры описана с помощью линейного уравнения с постоянным температурным коэффициентом.

Ключевые слова - радиочастотная абляция, осложнения, термическое воздействие, защита биологических тканей, моделирование, метод термической защиты.

UDC 616.1-616.7

\section{THERMAL PROTECTION OF TISSUES DURING RADIOFREQUENCY ABLATION}

\author{
Hanzha V.O., student \\ ganzha.vsta1997@.gmail.com \\ Stasiuk Y.P., assistant \\ stasuyk.yuriy@gmail.com \\ Vovianko S. I., Assoc. Ph.D. \\ sivovianko@gmail.com \\ Faculty of Biomedical Engineering \\ National Technical University of Ukraine \\ "Igor Sikorsky Kyiv Polytechnic Institute" \\ Kyiv, Ukraine
}

Annotation - The using of radiofrequency exposure for the destruction of pathological tissues is widely used in many diseases. The most widely used method of radiofrequency ablation was in the treatment of arrhythmias due to the fairly high safety of the procedure. However, the presence of risks is part of all operations. Avoiding, or at least reducing complications caused by excessive thermal exposure is one of the ways to improve the procedure.

In this paper, a study of the effect of low temperature generated by the cooling applicator on the amount of destruction of heart tissues during radiofrequency ablation is conducted. This thermal protection method will allow you to avoid unnecessary damage. The studies were conducted using a model created in Comsol 5.4 Multiphysics. The dependence of electrical conductivity on temperature is described using a linear equation with a constant temperature coefficient.

Keywords - radiofrequency ablation, complications, thermal impact, protection of biological tissues, modeling of thermal protection method. 